\title{
Cine ești tu ca să-mi spui mie ce să fac? Despre politicieni și experți
}

\author{
conf. univ. dr. Radu Rizoiu \\ Facultatea de Drept, Universitatea București \\ Motto: Master of puppets I'm pulling your strings \\ Twisting your mind and smashing your dreams \\ Blinded by me, you can't see a thing \\ Just call my name, 'cause I'll hear you scream
}

Metallica, Master of Puppets

Rezumat: Pornind de la un text de-al lui Bertrand Russell, articolul analizează rolurile specifice pe care politicienii (care sunt reprezentanții dorințelor poporului) și experții (care dețin cunoașterea științifică) le au în societate. Deși niciuna dintre categorii nu poate singură să definească un set de reguli pentru întreaga societate, combinația dintre cele două poate constitui cheia unei organizări statale coerente. Pe baza acestei soluții, articolul sugerează că un sistem legislativ bun poate fi dezvoltate de politicieni (care exprimă dorințele populare) pe baza datelor științifice puse la dispoziție de experți (care dețin instrumentele pentru a explica și implementa noile reguli).

Cuvinte-cheie: reguli, politicieni, experți

\section{Who are you to tell me what to do? On politicians and experts}

\begin{abstract}
Starting from a text by Sir Bertrand Russell, the paper looks into the division of roles between the politicians (i.e. the representative of popular wishes) and the experts (i.e. the holders of scientific knowledge). While neither could be able to set a workable framework for organizing the society by itself, a combination between the two could hold the key of a successful constitution. Based on this finding, the paper suggests that a good set of rules could be developed by politicians (who aggregate people's desires) based on the scientific findings of the experts (who hold the tools to explain and implement new rules).
\end{abstract}

Keywords: rules, politicians, experts

În filmul Enemy at the Gates (2001), Jude Law și Joseph Fiennes joacă rolurile a doi tineri înrolați în Armata Roșie în timpul Bătăliei de la Stalingrad. Primul este un lunetist de excepție, al doilea un politician cu o bună cunoaștere a psihologiei mulțimilor (și o slabă înțelegere a naturii umane). Dincolo de romanțarea hollywoodiană a poveștii lui Vasilii Zaițev, filmul prezintă o interesantă paralelă între ceea ce trebuie făcut și modul în care acțiunea corectă trebuie ,împachetată" pentru public. Astfel, dincolo de analizele obiective ale strategilor care indicau faptul că rezistența pe aliniamentul fluviului Volga era esențial pentru a opri ofensiva germană care amenința să ocupe câmpurile petrolifere din Caucaz, Nichita Hrușciov (magistral jucat de Bob Hoskins) expune problema într-o altă lumină: ,The city bears the name of the Boss. It's more than a city, it's a symbol." (Ironia istoriei face ca același Hrușciov, ajuns Secretar General după moartea lui Stalin să fie cel care a decis schimbarea numelui orașului în Volgograd - nume care se păstrează și astăzi.) 
De ce am amintit acest film (nu foarte bun)? Pentru că în el avem un specialist (vă amintiţi de Sylvester Stallone în Specialistul (1994), un alt lunetist) și un politician. Acest duet pare să fie soluția pe care democrația o oferă pentru organizarea societății. Acum câțiva ani, în timpul unei guvernări ,tehnocrate” (adică atunci când specialiștii se presupunea că iau deciziile), am citit un eseu de-al lui Bertrand Russell intitulat Nevoia de scepticism politic și publicat în 1928 (tradus în românește în Bertrand Russell, Eseuri sceptice, editura Humanitas, București, 2015, p. 136-153). Teza acestui eseu poate fi rezumată cu un citat din debutul lui: „In prezent există două feluri foarte diferite de specialiști în chestiuni politice. Pe de o parte există politicienii practici din toate partidele; iar pe de alta există experții - în principal funcționari publici, dar și economiști, finanțiști, medici calificați etc. Fiecare dintre cele două categorii posedă o iscusință de un fel special. Iscusinţa politicianului constă în a ghici cum pot fi făcuți oamenii să creadă că un lucru sau altul le este avantajos, iar iscusința expertului este de a calcula ce este realmente avantajos, cu condiția ca oamenii să fie făcuți să creadă așa."

Altfel spus, politicienii își bazează autoritatea pe legitimitatea dată de alegeri (sprijinul popular), dar același proces îi face să fie partinici și să nu mai asculte opinia celor care nu i-au votat. Expertul, pe de altă parte, este (în principiu) apolitic și el se preocupă mai degrabă de adevărul științific, indiferent cât de „,vandabil” este acesta. În continuare, Russell explică defectele fiecărei categorii pentru a concluziona că o posibilă soluție ar fi aceea de a lăsa experților dreptul de a propune măsuri împreună cu justificarea acestora, iar apoi politicienii să fie puși să ,vândă” acele măsuri populaţiei pentru a vedea care dintre ele trec testul popular. (Vedem astăzi cum anumite informații ale unor experți sunt ,scăpate pe surse” în presă pentru a vedea reacția publicului și apoi soluțiile sunt adaptate de politicieni pentru a elimina acele aspecte care au determinat o respingere generală din partea populației.)

Pentru a înțelege de ce m-am gândit acum la acest eseu este pentru că, la un moment dat, Russell face următoarea exemplificare: „Medicii, dacă ar deține puterea, ar putea inventa mijloace de eradicare a bolilor infecțioase, cu condiția ca legile lor să fie respectate; dacă însă aceste legi devansează cu mult opinia publică, ele vor fi ocolite". Vi se pare cunoscută situaţia? În ultimele zile am văzut cum a funcționat acest mecanism. La începutul crizei, politicienii au încercat să cosmetizeze situația explicând că măsurile de distanțare socială sunt simple recomandări, moment la care expertul a intervenit spunând că trebuie să le tratăm ca pe obligații. Recent, atunci când un (alt) expert a susținut că măsurile de izolare trebuie înăsprite pentru a avea siguranţa că virusul este ținut sub control, politicienii au preferat să-l destituie în fața protestului popular. Cu ceva timp înainte, un alt (pretins) expert (aflat într-o funcție politică) făcuse o altă afirmație hazardată care 1a costat funcția... Și peste Ocean vedem o relație tensionată între politicieni (Donald Trump) și experți (Anthony Fauci).

\section{Cine face regulile?}

De când am început să scriu de spre reguli, poate cele mai frecvente (și fervente) întrebări pe care le-am primit au fost legate de abilitatea unei persoane sau instituţii de a edicta reguli pe care alții să le respecte. Oare cine poate susține că poate să creeze un text normativ care apoi să aibă valoare obligatorie pentru o întreagă colectivitate? De aici o serie de reproșuri legate de calitatea legii în zilele noastre. De-a lungul timpului, problema acestui tip de autoritate a fost ocultată. Astfel, în preistorie, regulile veneau de la vraci (prin revelație) sau de la bătrânii tribului (din experiență). Acest tipar pare să fi supraviețuit peste milenii, modelul regăsindu-se în Evul Mediu când revelația era asociată dreptului divin, iar experiența deriva din dreptul roman (privit ca proces istoric de decantare a unor principii universal valabile, dar și de inventar de soluţii practice pentru probleme curente). 
Astăzi ambele componente trec printr-un con de umbră. Religia nu mai pare capabilă să justifice regulile pe care le susține cu argumente convingătoare. (Dezbaterile din jurul referendumului pentru familie au demonstrat o lipsă de argumente cel puțin la fel de mare pe cât au fost pasiunile implicate.) Principiile date de experiență pierd și ele teren pentru că, pe de o parte, (post)modernismul pare a îmbrățișa relativismul, iar pe de altă parte pentru că sunt tot mai puțini cei care au timp sau aplecare pentru a vedea cum au rezolvat generațiile anterioare o anumită problemă. Așa că regulile au ajuns să fie făcute ad-hoc, în funcție de necesitățile (sau interesele) momentului. Și nu spun că este greșit să rescriem regulile pentru noile realități ale epocii moderne, dar cred că modernitatea este mai redusă decât ne place uneori să credem. Dacă îl citim pe Aristotel, vom vedea că mare parte din soluțiile sale sunt perfect aplicabile astăzi, la peste 2000 de ani diferență. Sau vedem cum afirmațiile lui Bertand Russell de acum aproape 100 de ani sunt încă valabile.

Dar haideți să plecăm de la premisa că este nevoie de reguli noi. Cine le va face? Păi putem merge pe linia afirmată de un politician acum câțiva ani, când a răstălmăcit sloganul lui Obama (yes, we can!) sub forma ,,pentru că putem”. Putem deci să-i lăsăm pe politicieni să facă reguli după cum consideră ei că este bine. Dar s-ar putea să observăm că orizontul unora dintre ei este limitat la ziua de mâine (oricum, nu prea se are în vedere un interval mai mare decât ciclul electoral, ceea ce face ca în ultimul an al unui asemenea ciclu să ne trezim cu o serie de reguli ciudate) şi la sfera personală de experiență. Adică, în mod trivial, regulile sunt făcute ,,pentru ei”. Sau putem să ne trezim cu reguli pe care nici măcar cei care le-au făcut nu le înțeleg, pentru că sunt pur și simplu prost scrise. La extrema cealaltă, putem să-i lăsăm pe experți să facă regulile, dar atunci s-ar putea să ne trezim în situația în care cel mai bine este să nu ieșim deloc din casă, să mâncăm rațional și să facem în fiecare zi sport.

Soluția lui Russell mi se pare o variantă mult mai bună, pentru că ea presupune o conlucrare care poate aplica mecanismul checks and balances la nivelul redactării normei. Astfel, nici politicienii nu pot adopta legi iraționale, dar nici experții nu pot să ne ignore umanitatea. Într-o prelegere susţinută în 1957 la BBC (Political Judgment), Isaiah Berlin dezvoltă oarecum ideea lui Russell și oferă exemple din istorie în care pretenția de a trata politica (și societatea umană) ca pe un experiment științific a condus la rezultate dezastruoase. Altfel spus, soluțiile ,științifice” trebuie filtrate prin sita bunului simț, a rațiunii practice. În definitiv, toate utopiile au sfârşit prost, de la Platon până la comunism.

Totuși, nimeni nu poate să se bazeze pe intuiție și noroc la infinit. „Ne dăm noi seama pe parcurs" nu este o strategie pe termen lung. (Oare de aceea România nu are nici astăzi o strategie guvernamentală decât, ,pe hârtie”?) Să ne amintim că în 1996, politicienii au simțit nevoia să se laude că vor aduce „15.000 de specialiști”. Nu contează aici demagogia implicată și care i-a făcut să piardă apoi spectaculos în 2000, ci faptul că simțul politic le-a spus că asta doresc oamenii, iar oamenii i-au votat (și) pentru asta.

\section{Câteva sugestii}

Vestea bună este că avem absolut toată infrastructura instituţională pentru a pune în operă ideea lui Russell. Orice politician are prin lege un aparat tehnic menit să fie format din experți care să îl ajute la sarcinile sale. Între acești specialiști se pot număra și persoane care se pricep la anumite domenii specializate, iar nu numai specialiști în relații publice. Apoi, fiecare instituție populată de politicieni are un aparat administrativ unde se găsesc specialiști. Proiectele de legi nu sunt scrise de miniștri, ci de un expert angajat al ministerului respectiv. Există astăzi o foarte mare deschidere către valorificarea opiniilor specialiștilor. De exemplu, la deschiderea anului universitar 2019-2020, ministrul justiției își exprima intenția de a implica mediul academic în 
activitatea de legiferare de la nivelul Ministerului Justiției. Înalta Curte de Casație și Justiție solicită în mod curent opinia specialiștilor în cadrul unui proces similar celui normativ, atunci când analizează chestiuni generale și își propune să ofere o interpretare unitară a unor dispoziții legale.

În plus faţă de epoca în care scria Russell, astăzi există o pleiadă de organizații care pretind a populariza opiniile specialiștilor. Este vorba, pe de o parte, de acele organizații neguvernamentale care își propun să ofere soluții pentru politici publice, dar și de entităţile orientate spre profit care își dau seama că sustenabilitatea activității lor depinde de existența unei organizări corecte a societății. Politicile de corporate social responsibility sunt astăzi extrem de numeroase. În plus, analizele științifice sunt ușor disponibile prin diseminarea realizată de publicațiile generaliste. Astăzi este mult mai dificil să fie ,ascunsă” o informație vitală, așa cum s-a întâmplat în Uniunea Sovietică a anilor ' 80 cu studiul care putea avertiza asupra pericolului pe care o repornire la cald a reactorului nuclear de la Cernobîl îl poate produce.

Așadar, resursele există, ele trebuie doar organizate și mobilizate, dar, în special, ele trebuie utilizate. Și pentru a fi utilizate, este nevoie de doi factori: încredere și competență. În ceea ce privește încrederea, atât experții, cât și politicienii trebuie să învețe să aibă încredere unii în ceilalți. Câtă vreme ei urmăresc obiective legitime, lipsa de încredere este contraproductivă. În ceea ce privește competența, politicienii ar trebui să învețe să dezvolte o interfață cu experții prin intermediului aparatului lor de lucru. Membrii (non-politici ai) staff-ului politicianului trebuie să aibă capacitatea de a interacționa cu experții și de a putea să discearnă care persoane dețin cunoștințe relevante în anumite domenii. De cealaltă parte, experții trebuie să iasă din „laborator” și să-și expună ideile în cadrul unor forumuri publice pentru a le face cunoscute ,în piață”. (În anii trecuți fuseseră realizate studii epidemiologice care explicau măsurile care ar trebui luate în caz de pandemie, dar ele au fost ignorate, rămânând cantonate în cercul specialiștilor. Când criza a lovit, ele au fost „dezgropate”.) Vedem astfel de mișcări în ultima perioadă în tot felul de domenii. Să nu uităm că cel mai amplu proiect legislativ al ultimelor decenii (cele patru Coduri) a fost realizat prin implicarea directă a specialiștilor și apoi discutarea soluțiilor propuse în comisii specializate ale Parlamentului. (Faptul că ulterior o serie de soluții au fost puse sub semnul întrebării a fost determinat de lipsa de pregătire administrativă a sistemului pentru a permite soluții novatoare. Astăzi vedem cum soluțiile care au fost declarate neconstituționale acum câțiva ani ar fi fost extrem de utile într-o vreme în care justiția ar trebui să fie mai flexibilă, iar birocrația redusă.)

Dacă ar fỉ să rezum, într-o democrație constituțională procesul legislativ nu ar trebui să fie apanajul politicienilor sau al experților. Așa cum se întâmplă și în filmul evocat la început, lucrurile merg bine doar atunci când politicianul și expertul lucrează împreună. Sau, așa cum încearcă să ne convingă Jürgen Habermas, este nevoie de un continuu dialog (instituțional) pentru identificarea soluției corecte. Dar, pentru ca acest tandem să funcționeze, este nevoie de politici publice și de strategii care să fixeze obiective și să fie autonome de doctrine politice (sau științifice).

Materialul a fost publicat în revista online a Facultății de Drept, $\underline{\text { AUBD - Forum Juridic nr. }}$ $\underline{2 / 2020 .}$ 